\title{
The habitat type and trophic state determine benthic macroinvertebrate assemblages in lowland shallow lakes of China
}

\author{
Zhixin HU, ${ }^{1}$ Xu SUN,${ }^{1}$ Yongjiu CAI, ${ }^{2}$ Liyun GUO, ${ }^{1}$ Qiankun CHEN,,${ }^{1}$ Tao LIU, ${ }^{1}$ Fei SHI, ${ }^{1}$ Liuyan YANG ${ }^{1 *}$ \\ ${ }^{1}$ State Key Laboratory of Pollution Control and Resource Reuse, School of the Environment, Nanjing University, 210023 Nanjing; \\ ${ }^{2}$ Key Laboratory of Watershed Geographic Sciences, Nanjing Institute of Geography and Limnology, Chinese Academy of Sciences, \\ 210008 Nanjing, China \\ *Corresponding author: yangly@nju.edu.cn
}

\begin{abstract}
Benthic macroinvertebrates play important roles in shallow lake ecosystems. Several studies based on qualitative comparisons of the amount of macrophytes were carried out to relate benthic macroinvertebrate assemblages to habitat conditions in shallow lakes. Our main aim was to analyze the effects of habitat type and trophic state on taxonomic composition and abundance of benthic macroinvertebrates in lowland shallow lakes based on quantitative classification of habitat types. The benthic macroinvertebrate assemblages were investigated in eight shallow lakes of eastern China in four seasons. A total of 33 species was collected from these lakes, including four Oligochaeta, eight Chironomidae, eight Gastropoda, four Bivalvia and nine other miscellaneous species. According to the ratio of the dry weight of macrophytes to the dry weight of phytoplankton, the study lakes were separated into three lake types; macrophytedominated, transitional, and algae-dominated regions. The total abundance of macroinvertebrates was significantly higher in the group of algae-dominated regions than in the macrophyte-dominated regions. Scrapers had the highest abundance in the macrophyte-dominated regions. Univariate and multivariate analyses results showed that abundance, biomass and characteristic species of benthic macroinvertebrates were affected by their habitat types. The abundance and biomass of macroinvertebrates showed significant positive correlations with the trophic state index (TSI). TSI and turbidity were significantly correlated with DC1 (Axis 1 of detrended correspondence analysis), while Chlorophyll a and the ratio of the dry weight of macrophytes to the dry weight of phytoplankton were significantly correlated with DC2. The findings indicated that the habitat type and trophic state were the key factors determining the structure of macroinvertebrate assemblages in lowland shallow lakes. Our study was one of the few studies that had demonstrated the distinct influence of habitat type on macroinvertebrate assemblages in shallow lakes according to the ratio of the dry weight of macrophytes to the dry weight of phytoplankton.
\end{abstract}

Key words: Habitat type; eutrophication; benthic macroinvertebrate; shallow lake.

Received: April 2015. Accepted: January 2016.

\section{INTRODUCTION}

Lakes are globally recognized as being particularly important for plankton, macroinvertebrate, aquatic plant and fish conservation, contributing highly to freshwater biodiversity at a regional scale (Bazzanti et al., 2010). Shallow lakes differ from deep ones by the lack of permanent water stratification, which increases the impact of water-sediment interface processes upon a lake ecosystem (Scheffer, 1998). Furthermore, shallow lakes are often located in lowland regions that are significantly affected by anthropogenic disturbances (Havens et al. 2007). Eutrophication has been considered a major threat to shallow lakes in lowland areas of the world (Havens et al. 2007; Heisler et al., 2008). The most common effects of eutrophication in shallow lakes are excessive increases in the productivity and biomass of algae or macrophytes. According to the theory of alternative stable states, there is the shift from a macrophyte-dominated clear water state to a turbid state dominated by phytoplankton (Scheffer et al., 2001). Bachmann et al. (2002) devised an operational definition for the lake habitat types of the macrophytedominated, transitional, and algae-dominated lakes. Unfortunately, only few studies were carried out in shallow lakes on quantitative classification of habitat types (Bachmann et al., 2002; Hu et al., 2014).

Benthic macroinvertebrates are an important factor influencing the function of shallow lakes (Lindegaard, 1994). They consume detritus and algae and provide food to other aquatic animals (Palmer et al., 2000; Al-Shami et al., 2010). They also change the physical-chemical parameters of water and sediments (Covich et al., 1999; Vaughn and Hakenkamp, 2001; Longhi et al., 2013) and facilitate energy flows and nutrient cycling in shallow lake ecosystems (Covich et al., 1999; Vanni, 2002). Therefore, it's necessary to reveal factors determining the taxonomic composition and structure of macroinvertebrates in the open water zone of shallow lakes (Żbikowski and Kobak, 2007). It has been shown that benthic macroinvertebrate distribution is affected by sediment quality, contaminants, biotic factors, 
oxygen conditions and macrophytes (Mackay, 1992; Phipps et al., 1995; Dinsmore and Prepas, 1997; Weatherhead and James, 2001; Cai et al., 2011). In addition, macroinvertebrate indices have been used frequently for evaluating aquatic ecosystem health combined with water quality monitoring (Song et al., 2007; Gabriels et al., 2010; KeizerVlek et al., 2012; Clews et al., 2014; Traversetti et al., 2015). Therefore, understanding the strucuture of macroinvertebrate assemblages and the relationship with habitat type and environmental variables is essential to conservation of shallow lake ecosystems (Principe and Corigliano, 2006; Wang et al., 2007; Chen et al., 2013).

Microdistribution of macroinvertebrates is well known in rivers and lakes where most results indicate that environmental aspects, including the heterogeneity of habitats, are generally mainly responsible for the spatial distribution of taxa in these freshwater ecosystems (Statzner and Higler, 1986; Lloyd et al., 2006; Bazzanti et al., 2010). Several studies have attempted to relate the benthic assemblage to habitat conditions in shallow lakes (Hargeby et al., 1994; Żbikowski and Kobak, 2007; Cai et al., 2011; Cai et al., 2012; Pan et al., 2012). However, these studies were conducted based on qualitative comparisons of the amount of macrophytes (Żbikowski and Kobak, 2007; Cai et al., 2011; Pan et al., 2012). Thus, further studies are still needed on the benthic macroinvertebrate assemblage structure and the possibility of regulating factors in shallow lakes. The aim of our research was to elucidate the effects of habitat type and trophic state on taxonomic composition and abundance of benthic macroinvertebrates in some shallow lakes of China based on quantitative classification of habitat types.

\section{METHODS}

\section{Study area}

This study focuses on eight shallow lakes in eastern China (Fig. 1). These lakes are located in a subtropical to temperate humid monsoon climate zone with an annual average temperature of $13.5-16.0^{\circ} \mathrm{C}$ and an annual average precipitation of 779-1431 mm (Wang and Dou, 1998). They are also a prominent feature in the landscape of the lowlands of eastern China, with water levels ranging from 3.14 to $23.00 \mathrm{~m}$ and lake surface areas ranging from 3.7 to 2338 $\mathrm{km}^{2}$ (Wang and Dou, 1998). Lake Taihu and Lake Hongze were the third and fourth largest freshwater lakes in China, respectively. A total of 42 sites were collected as follows: fifteen, eight, and four sampling sites were selected in Lakes Taihu, Hongze and Gucheng, respectively, and three sampling sites were arranged in the other five lakes (Fig. 1).
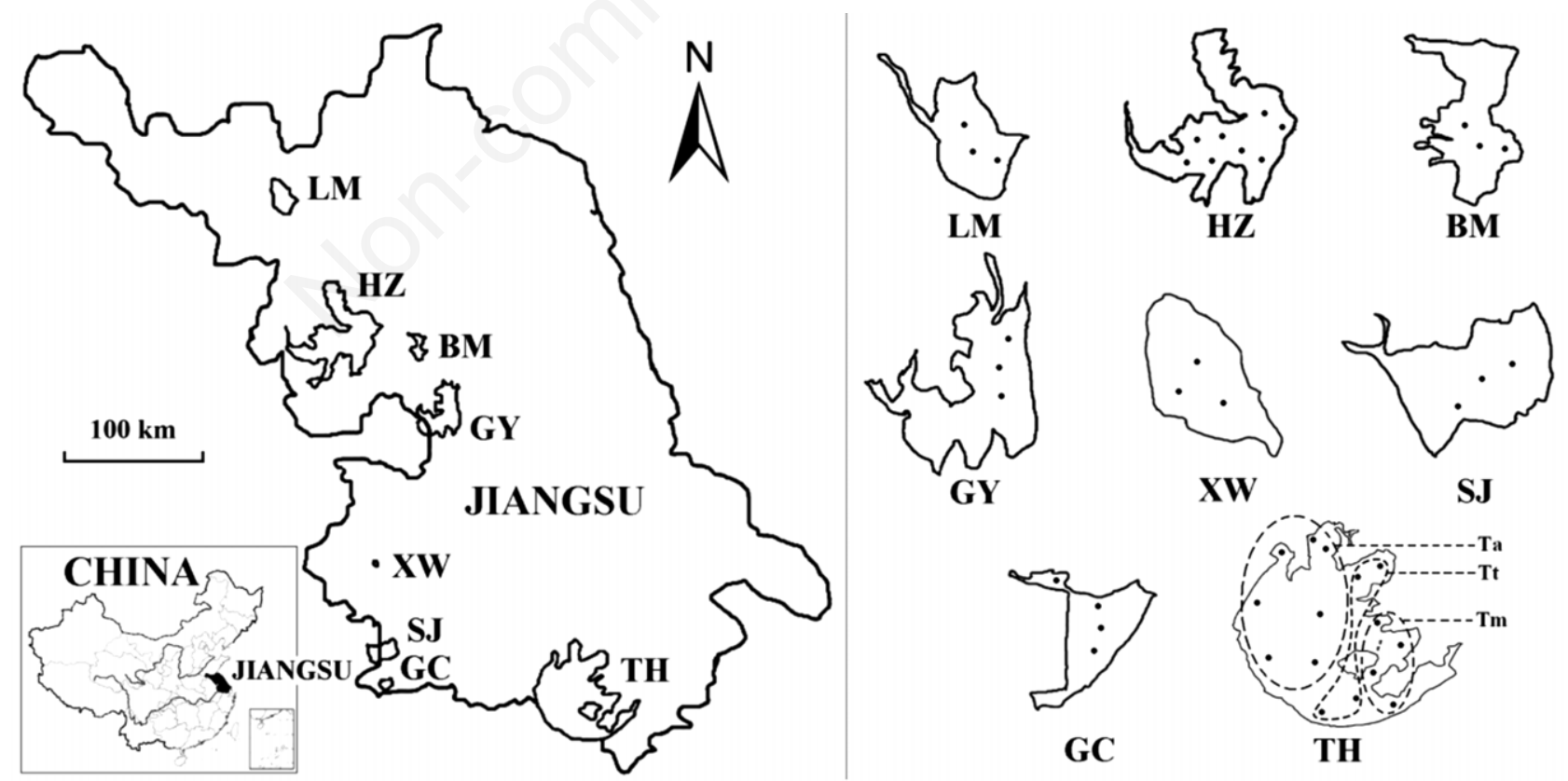

Fig. 1. Map of eight lakes in Jiangsu province. Solid circles represent the sampling sites in these lakes. LM, Lake Luoma; HZ, Lake Hongze; BM, Lake Baima; GY, Lake Gaoyou; XW, Lake Xuanwu; SJ, Lake Shijiu; GC, Lake Gucheng; TH, Lake Taihu. Ta included the seven sampling sites located in the algae-dominated regions of Lake Taihu, Tm included the four sampling sites located in the macrophyte-dominated regions of Lake Taihu, Tt included the remaining four sampling sites located in the transitional regions between these two types of habitat of Lake Taihu. 


\section{Macroinvertebrate sampling and laboratory processing}

Benthic samples were collected quarterly at these stations in July and October of 2011 and February and April of 2012. Samples were collected using a $0.0625 \mathrm{~m}^{2}$ modified Peterson grab, with two replicate grabs comprising a sample, and were washed in situ through a $250-\mu \mathrm{m}$ sieve. The animals were preserved in 5\% buffered formalin solution and the samples were led to the laboratory for identification. Organisms were identified to the lowest feasible taxonomic level, counted, blotted dry and weighed on an electronic balance to determine wet weight.

\section{Measurement of environmental parameters}

Water samples were collected simultaneously from 0.5 $\mathrm{m}$ below the water surface using a synthetic glass water sampler in the shallow lakes. Samples were taken in PVC flasks for analysis of chlorophyll $a(\mathrm{Chl}-a)$ and nutrient contents. Water depth was estimated with a portable ultrasonic water depth sensor. A 30-cm Secchi disk was used to detect transparency (Trans) in situ. Electrical conductivity, oxidation-reduction potential (ORP), $\mathrm{pH}$, turbidity and dissolved oxygen (DO) were measured at each station with a Multi-Parameter Water Quality Instrument YSI6600V2. Total nitrogen (TN), total phosphorus (TP) and chemical oxygen demand (COD) in the water column were measured in the laboratory according to standard methods (Jin and Tu, 1990). Chlorophyll $a$ (Chl-a) content was calculated according to Lorenzen (1967) from spectrophotometric measurements after extraction in $90 \%$ hot ethanol. Meanwhile, the dissolved organic carbon (DOC) content was analyzed by SHIMADZU TOC-5000A in State Key Laboratory of Pollution Control and Resource Reuse, China. The error estimates were calculated as the differences compared to the detected measurements with the average value of the triplicates.

Based on macrophyte coverage, 5-10 quadrats were selected around the sampling sites in the lakes when macrophytes were present. A single $0.25 \mathrm{~m}^{2}$ sample of macrophytes was taken in each quadrat and each species was recorded. The sampled macrophytes were placed into nylon mesh bags, which were spun to remove excess water, and weighed using an electronic balance. The sampled macrophytes were taken back to the laboratory as soon as possible after sampling. Dry weights of macrophytes were measured after at least $6 \mathrm{~h}$ drying at $105^{\circ} \mathrm{C}$. The average dry weights of emergent, floating-leaved, and submersed plants $\left(\mathrm{g} \mathrm{m}^{-2}\right)$ were determined for each sampling site. Areal average content of macrophytes was converted to dry weight per unit volume divided by the mean water depth.

\section{Data analysis}

According to the operational definition for lake types devised by Bachmann et al. (2002), the lakes were con- sidered as macrophyte-dominated lakes when the dry weight ratio of macrophytes to phytoplankton (Rmp) was more than 100. The lakes were considered as algae-dominated lakes when the dry weight ratio of macrophytes to phytoplankton was less than 1 . The remaining lakes were considered as transitional type. Dry weights of phytoplankton were estimated with the chlorophyll $a$ values multiplied by 70 (Bachmann et al., 2002).

The classical Carlson trophic state index (Carlson, 1977) developed by Jin and Tu (1990) was taken to assess the trophic status of these shallow lakes. The trophic state index (TSI) was calculated using five limnological parameters including Chl- $a\left(\mu \mathrm{g} \mathrm{L}^{-1}\right), \mathrm{TN}\left(\mathrm{mg} \mathrm{L}^{-1}\right)$, TP $\left(\mathrm{mg} \mathrm{L}^{-1}\right)$, Transparency $(\mathrm{m})$ and COD $\left(\mathrm{mg} \mathrm{L}^{-1}\right)$. The comprehensive TSI was calculated according to the following equation:

$$
\operatorname{TSI}(\Sigma)=\sum_{j=1}^{n} W_{j} \times T S I(j)
$$

where $T S I(j)$ is the $j$-th trophic state index for the $j$-th indicator, $W_{j}$ is the weighting factor for the $j$-th indicator, and $n$ is the total number of assessment indicators. For Chinese lakes, the $W_{j}$ values of Chl- $a$, TP, TN, Transparency and COD could be calculated as $0.2663,0.1879$, $0.1790,0.1834$ and 0.1834 , respectively (Jin, 1995).

The equations for single parameters are (Jin, 1995):

$$
\begin{aligned}
& \operatorname{TSI}(\mathrm{Chl}-a)=10 \times(2.500+1.086 \times \ln \mathrm{Chl}-a) \\
& \operatorname{TSI}(\mathrm{TP})=10 \times(9.436+1.624 \times \ln \mathrm{TP}) \\
& \operatorname{TSI}(\mathrm{TN})=10 \times(5.453+1.694 \times \ln \mathrm{TN}) \\
& \operatorname{TSI}(\text { Trans })=10 \times(5.118-1.940 \times \ln \text { Trans }) \\
& \operatorname{TSI}(\mathrm{COD})=10 \times(0.109+2.661 \times \ln \mathrm{COD})
\end{aligned}
$$

Prior to analysis, the abundance and biomass data were converted to individual $\mathrm{m}^{-2}$ and wet weight $\mathrm{g} \mathrm{m}^{-2}$, respectively. We averaged the biological and environmental data across the sampling sites in each lake. The biological and environmental data were also averaged across the four times when we focused on the effects of habitat type and trophic state on benthic macroinvertebrate assemblages. Simple descriptors of assemblage structure were calculated, including the abundance and biomass of total macroinvertebrates and the four common taxonomic groups (Oligochaeta, Bivalvia, Gastropoda and Chironomidae). Species were also divided into five functional feeding groups (gatherers, filterers, predators, scrapers and shredders) according to their food source and feeding mechanism. The relative contribution of the five functional feeding groups was evaluated in terms of abundance. Variations of these descriptors among various lake types were tested by one-way ANOVA following a post hoc Tukey test, which was performed with the SPSS 13.0 statistical package. 
Multivariate statistical analyses were applied to examine differences in assemblage structure among various lake types, using PRIMER 5.0. Macroinvertebrate assemblage structure was compared among habitats using analysis of similarities (ANOSIM) (Clarke, 1993) based on a Bray-Curtis similarity matrix obtained from square-roottransformed invertebrate abundance data. Pairwise comparisons were conducted if the global test statistic $R$ was significant, at $\mathrm{P}<0.05$, and similarity percentage (SIMPER) procedures were also performed to determine the characteristic species for the three habitats (Clarke, 1993).

To assess the similarities and differences between sampling sites, an ordination method was performed to summarize biotic variables (Traversetti et al., 2014). A detrended correspondence analysis (DCA) on macroinvertebrate assemblage abundances was used to obtain a two-dimensional plot. DCA was performed using PAST 3.07 and the abundance data was square-root-transformed. Additionally, a series of Spearman's correlations between the first 2 DC axes and the considered parameters were performed to identify driving forces of the macroinvertebrate assemblages. Correlation analysis was performed with the SPSS 13.0 statistical package.

\section{RESULTS}

\section{Limnological characteristics}

Average values for limnological parameters in the study lakes are presented in Tab. 1. Chl- $a$ contents in the study varied between $1.85 \pm 0.27$ and $11.36 \pm 0.65 \mu \mathrm{g} \mathrm{L} \mathrm{L}^{-1}$. $\mathrm{TN}, \mathrm{TP}$ and COD contents ranged from $1.215 \pm 0.336$ to $2.476 \pm 1.101,0.046 \pm 0.010$ to $0.175 \pm 0.098$, and $2.84 \pm 0.20$ to $4.83 \pm 0.48 \mathrm{mg} \mathrm{L}^{-1}$, respectively. Water transparency varied from $0.41 \pm 0.10 \mathrm{~m}$ in Lake Hongze to $1.56 \pm 0.10 \mathrm{~m}$ in Lake Luoma. TSI ranged from $42.93 \pm 2.08$ to $54.57 \pm 4.37$, and Rmp ranged from $0.05 \pm 0.04$ to $610.14 \pm 295.85$ in the study lakes.

The eight lakes were divided into three groups according to the yearly means of the dry weight ratio of macrophytes to phytoplankton (Tab. 1). Especially, the 15 sampling sites were placed into three groups in Lake Taihu, a large shallow freshwater lake in China (Fig. 1). In the eight lakes, algae-dominated regions included Lake Hongze (HZ), Lake Xuanwu (XW), Lake Shijiu (SJ) and the algae-dominated regions of Lake Taihu (Ta). Macrophyte-dominated regions included Lake Baima (BM) and the macrophyte-dominated regions of Lake Taihu (Tm). Lake Luoma (LM), Lake Gaoyou (GY), Lake Gucheng (GC) and the transitional regions of Lake Taihu (Tt) were placed into a transitional habitat group.

\section{Abundance and biomass}

A total of 33 taxa were recorded in the 168 quantitative samples, including four Oligochaeta, eight Chirono-

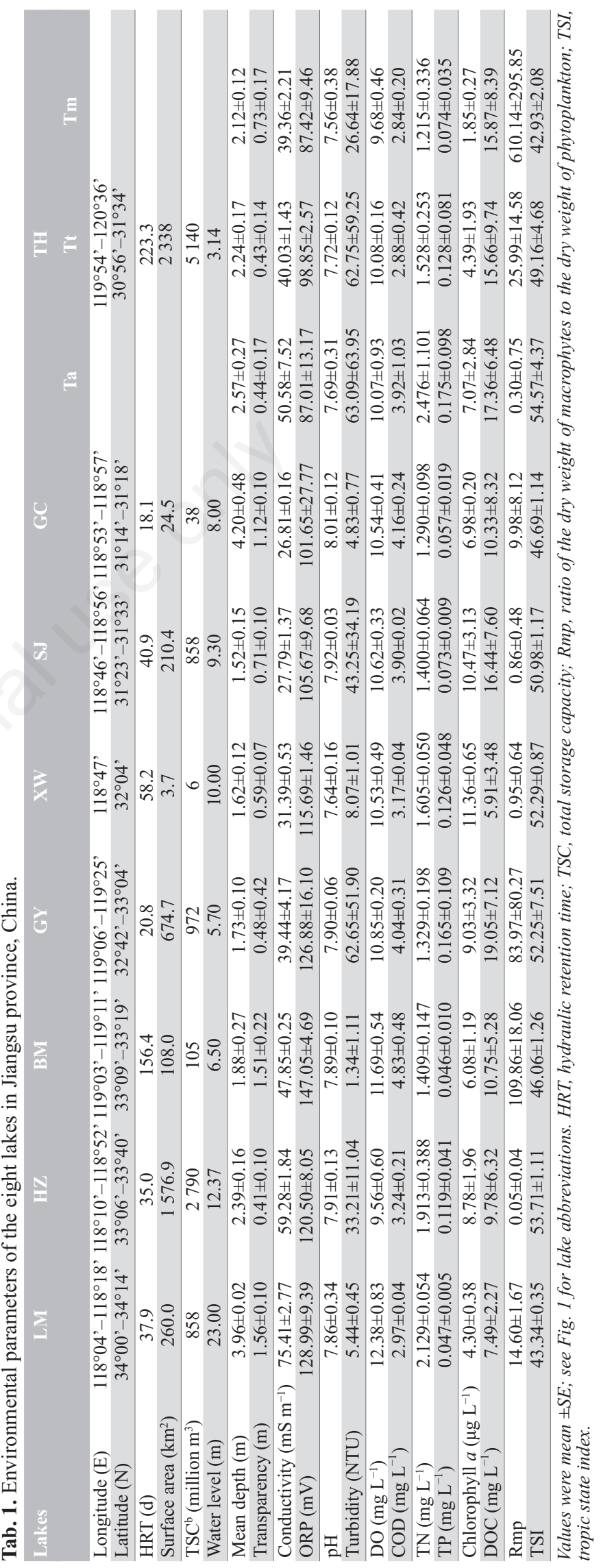


midae, eight Gastropoda, four Bivalvia and nine other miscellaneous species (Supplementary Tab. 1). In general, Oligochaeta, Gastropoda and Bivalvia were the dominant taxa in the three habitats (Fig. 2). Concerning the abundance of the four common taxonomic groups, the algaedominated regions and transitional regions were dominated by Oligochaeta and Bivalvia. In contrast, a significantly higher abundance of Gastropoda was observed in the macrophyte-dominated regions compared with the algae-dominated regions and transitional regions (Fig. 2). In contrast to abundance, the total biomass was dominated by Bivalvia and Gastropoda, due to their relatively large body sizes and the total biomass of macroinvertebrates did not exhibit significant differences among habitats (Fig. 2). By assigning individuals to their feeding groups, gatherers represented a relatively high proportion of the total abundance in most of the study lakes (Fig. 3). In contrast, scrapers showed the highest abundance in the macrophyte-dominated regions and accounted for $82.22 \%$ and $63.23 \%$ of the total abundance in Lake Baima (BM) and the macrophyte-dominated regions of Lake Taihu $(\mathrm{Tm})$, respectively (Fig. 3). Predators and shredders accounted for small percentages of the total abundance in all habitats (Fig. 3).

The total abundance of macroinvertebrates was significantly higher in the algae-dominated regions (mean, 356.77 ind. $\mathrm{m}^{-2}$ ) than in the macrophyte-dominated regions $\left(124.21\right.$ ind. $\left.\mathrm{m}^{-2}\right)(\mathrm{P}<0.05$ by one-way ANOVA). In contrast to abundance, the total biomass of macroinvertebrates was not significantly different among the three habitats (Fig. 4). Correlation analysis revealed that the abundance of macroinvertebrates had significant negative correlation with the dry weight ratio of macrophytes to phytoplankton $(\mathrm{P}<0.01)$. There was no significant correlation between the biomass of macroinvertebrates and the dry weight ratio of macrophytes to phytoplankton (Fig. 5a). In contrast, the abundance and biomass of macroinvertebrates had significant positive correlations with the trophic state index of lake water body $(\mathrm{P}<0.01)$ (Fig. $5 b)$.

\section{Multivariate analyses}

One-way ANOSIM analyses also indicated that the benthic assemblage differed significantly between the algae-dominated regions and macrophyte-dominated regions (Tab. 2). The SIMPER procedures indicated that the algae-dominated regions were mainly characterized by species of Oligochaeta (Branchiura sowerbyi and Limnodrilus hoffmeisteri), Gastropoda (Bellamya aeruginosa) and Bivalvia (Corbicula fluminea) (Tab. 3). Nephtys oligobranchia and Notomastus latericeus were also important species in the algae-dominated regions. Benthic assemblages characterized in the transitional regions were species of Oligochaeta (B. sowerbyi and $L$. hoffmeisteri), Chironomidae (Chironomus semireductus),
Gastropoda (B. aeruginosa) and Bivalvia (C. fluminea) (Tab. 3). In contrast, the macrophyte-dominated regions were mainly characterized by gastropods (Tab. 3 ). Notably, some species (e.g., B. sowerbyi, L. hoffmeisteri, B. aeruginosa and $C$. fluminea) characterized two or three habitats. However, the abundance of these species varied greatly among habitats (Tab. 3). The DCA analysis showed that a clear distinction was obtained between macrophyte-dominated regions and algae-dominated re-

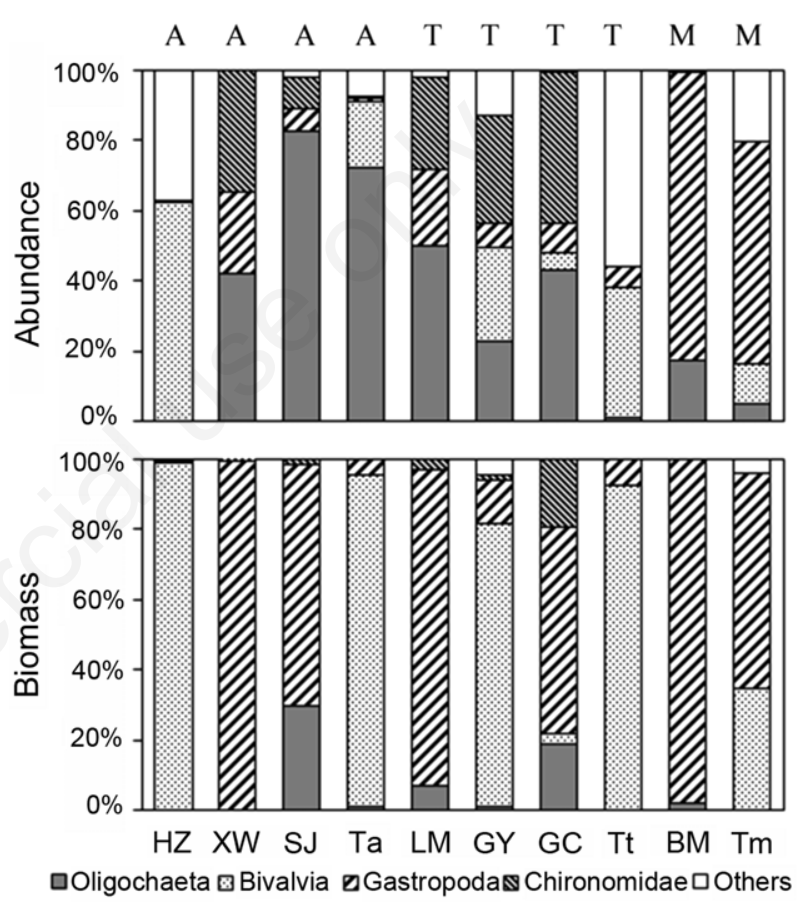

Fig. 2. The relative abundance and biomass of the four common taxonomic groups in the studied lakes. A, algae-dominated regions; T, transitional regions; $\mathrm{M}$, macrophyte-dominated regions.

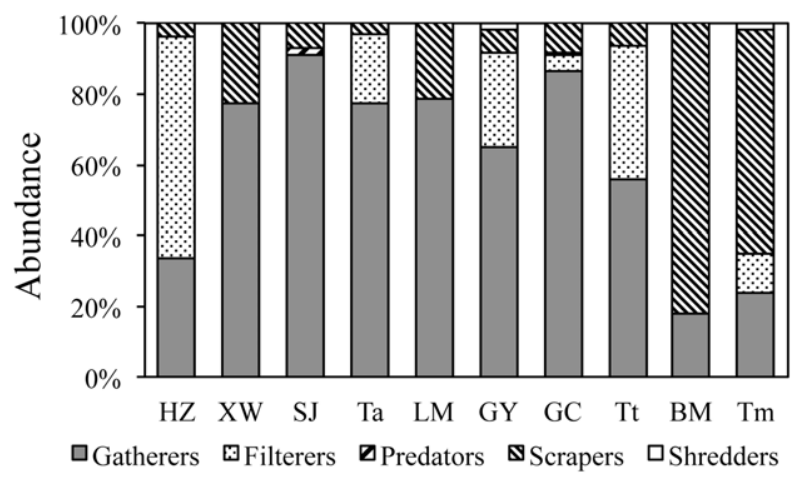

Fig. 3. The relative abundance (\%) of the different functional feeding groups in the studied lakes. 
gions (Fig. 6). The first two axes had eigenvalues of 0.612 and 0.306 , respectively. TSI and turbidity were significantly correlated with DC1, while Chl- $a$ and Rmp were significantly correlated with DC2 (Tab. 4).

\section{DISCUSSION}

\section{Relationship between benthic macroinvertebrate assemblages and habitats}

Our findings showed that abundance and characteristic species of macroinvertebrates differed significantly among the three habitats. The total abundance of macroinvertebrates was significantly higher in the algae-dominated regions than in the macrophyte-dominated regions (Fig. 4). In fact, macrophyte-dominated lake regions were covered by dense aquatic macrophytes in our study. The dry weight ratio of macrophytes to phytoplankton is an operational definition for lake habitats devised by Bachmann et al. (2002), and showed significant negative correlation with the abundance of macroinvertebrates (Fig. 5). Notably, the abundance of some species (e.g., B. sowerbyi, L. hoffmeisteri, B. aeruginosa and $C$. fluminea) varied greatly among habitats (Tab. 3), suggesting that the differences in the benthic assemblage between habitats mainly resulted from differences in the abundance of the taxa among various lake types.

Some previous studies have shown that there was a positive effect of macrophytes on benthic macroinvertebrate assemblages (Hargeby et al., 1994; Żbikowski and Kobak, 2007; Cai et al., 2011). Generally, macrophytes can provide habitats and foods for aquatic animals, which can increase spatial heterogeneity and allow more species of various ecological niches to coexist in a macrophytedominated lake (Padial et al., 2009; Bazzanti et al., 2010; Robinson and Doering, 2013). In addition, macrophytes provide more surface area for attachment by periphytons, which are a major component in the diet of macroinvertebrates (Jones et al., 1999; Cai et al., 2011). Our findings showed that scrapers had the highest abundance in the macrophyte-dominated regions (Fig. 3). Moreover, the activities of gastropods could effectively remove the organism layer on the surface of macrophytes, which benefitted the growth of aquatic plants. The macrophyte-dominated regions were mainly characterized by gastropods (Pan et al., 2012) and very few individuals were collected in the other habitats. Our findings are in accordance with the snail-macrophyte-epiphyte mutualistic hypothesis, which proposes that gastropods, macrophytes and periphytons could form a structure of mutualistic (Thomas, 1990; Underwood et al., 1992). In contrast, there is no such space structure in the algae-dominated regions, which could not provide the diversity of food conditions and restrict the species diversity, but some adaptive macroinvertebrates could increase to large numbers. For example, $L$. hoffmeisteri was one of characteristic species with the high mean abundance (156.97 ind. $\mathrm{m}^{-2}$ ) in the algae-dominated regions (Tab. 3).
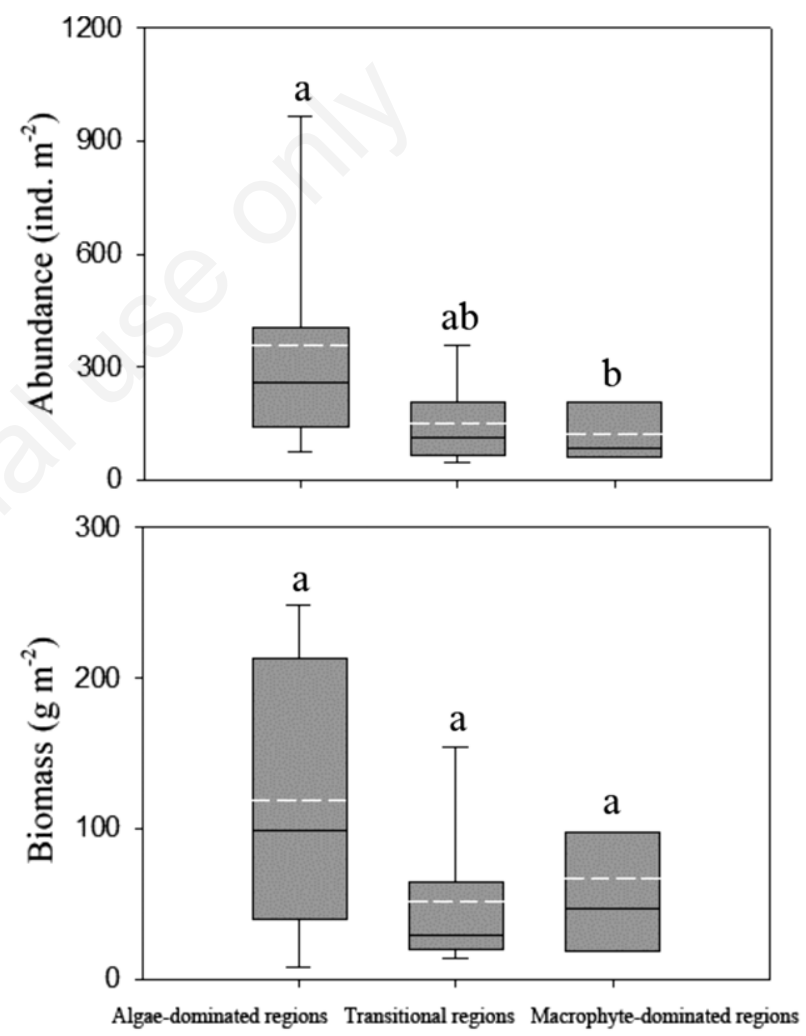

Fig. 4. Box-plots of benthic macroinvertebrate abundance and biomass in different habitats. The black and white dashed lines, lower and upper edges and bars of the boxes represent median and mean values, $25^{\text {th }}$ and $75^{\text {th }}$ percentiles and $10^{\text {th }}$ and $90^{\text {th }}$ percentiles, respectively. Different letters ( $a$ and b) indicate a significant difference between values, and ab indicates no significant difference between the values with those given a same letter ( $\mathrm{a}$ or $\mathrm{b}$ ), $\mathrm{P}<0.05$ by one-way ANOVA.

Tab. 2. One-way analysis of similarities (ANOSIM) of macroinvertebrate assemblage in different habitats.

\begin{tabular}{llcc} 
Pairwise comparison & Dissimilarity (\%) & P value & 0.042 \\
Algae-dominated regions $v s$ transitional regions & 67.79 & 0.43 & 0.521 \\
Algae-dominated regions $v s$ macrophyte-dominated regions & 82.07 & 0.03 & 0.458 \\
\hline Transitional regions $v s$ macrophyte-dominated regions & 74.15 & 0.03 \\
\hline
\end{tabular}




\section{Influence of eutrophication on benthic macroinvertebrate assemblages}

Benthic macroinvertebrates are used as indicators of pollution because of their sensitive to changes in physicochemical factors (Keizer-Vlek et al., 2012). Macroinver-
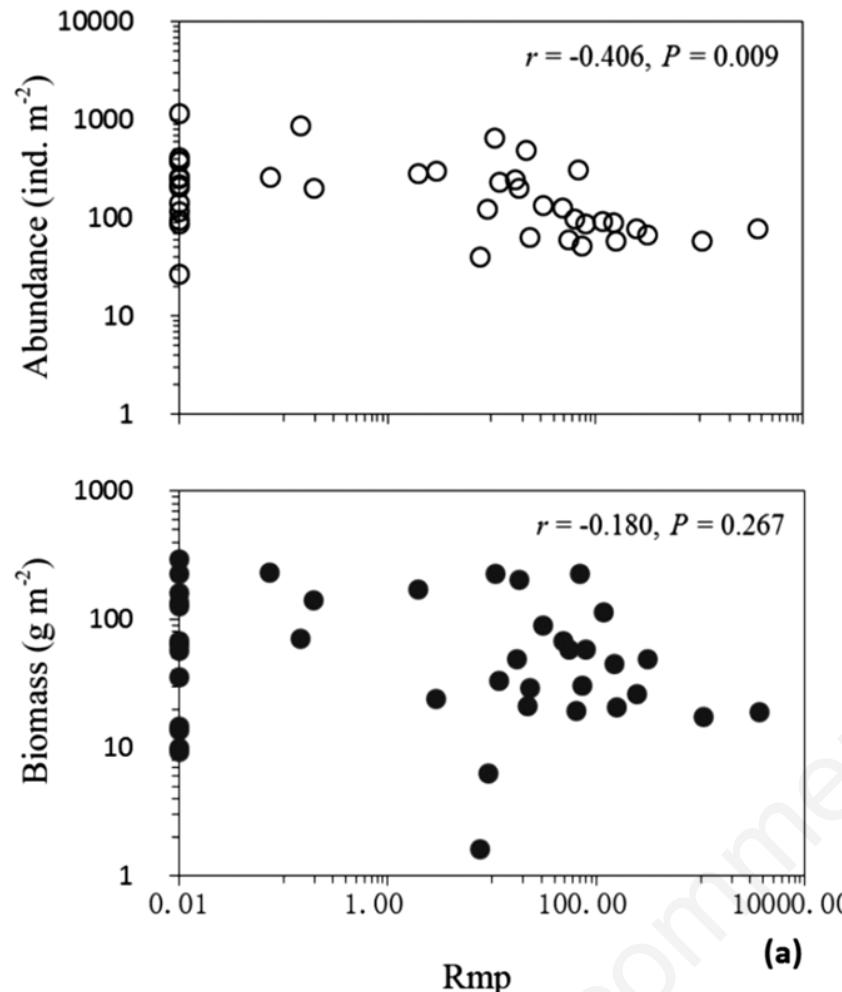

tebrates form an important component of an aquatic ecosystem and have functional importance in assessing the trophic status of that ecosystem (Traversetti et al., 2014). Since the abundance of benthic fauna depends on the physical and chemical properties of the substratum, changes of the benthic assemblage are indicative of
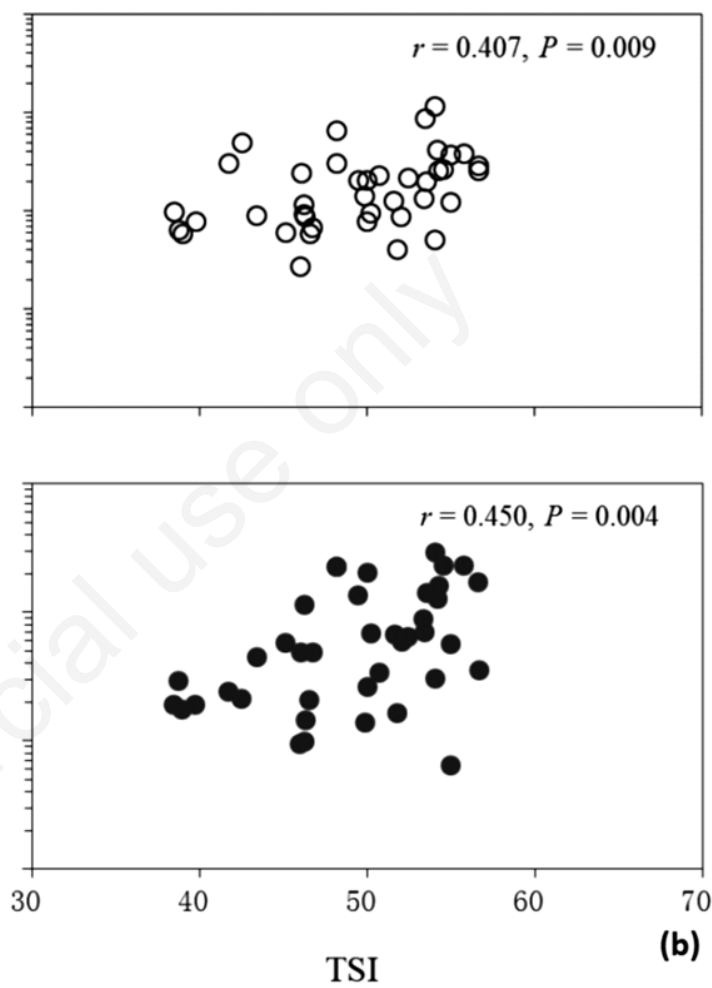

Fig. 5. Relationships between abundance, biomass of benthic macroinvertebrates and (a) dry weight ratio of macrophytes to phytoplankton (Rmp) and (b) trophic state index (TSI). Zero values of Rmp were plotted as 0.01 .

Tab. 3. Mean abundance (ind. $\left.\mathrm{m}^{-2}\right)$ of characteristic species for different habitats and their contributions (\%) to within-group similarity. The mean abundance of characteristic species and their contribution were calculated until the cumulative percentage reached $80 \%$.

\begin{tabular}{|c|c|c|c|c|c|c|}
\hline \multirow[t]{2}{*}{ Taxa } & \multicolumn{2}{|c|}{ Algae-dominated regions } & \multicolumn{2}{|c|}{ Transitional regions } & \multicolumn{2}{|c|}{ Macrophyte-dominated regions } \\
\hline & Abundance & Contribution & Abundance & Contribution & Abundance & Contribution \\
\hline $\begin{array}{l}\text { Oligochaeta } \\
\text { Branchiura sowerbyi } \\
\text { Limnodrilus hoffmeisteri }\end{array}$ & $\begin{array}{c}20.08 \\
156.97\end{array}$ & $\begin{array}{l}18.76 \\
31.72\end{array}$ & $\begin{array}{l}26.89 \\
15.76\end{array}$ & $\begin{array}{l}21.02 \\
10.80\end{array}$ & 2.01 & 8.34 \\
\hline $\begin{array}{l}\text { Chironomidae } \\
\text { Chironomus semireductus }\end{array}$ & & & 19.73 & 20.01 & & \\
\hline $\begin{array}{l}\text { Gastropoda } \\
\text { Bellamya aeruginosa } \\
\text { Alocinma longicornis } \\
\text { Parafossarulus striatulus }\end{array}$ & 22.66 & 6.75 & 7.69 & 20.33 & $\begin{array}{c}16.06 \\
10.62 \\
9.30\end{array}$ & $\begin{array}{l}31.33 \\
25.36 \\
20.99\end{array}$ \\
\hline $\begin{array}{l}\text { Bivalvia } \\
\text { Corbicula fluminea }\end{array}$ & 67.54 & 14.51 & 19.35 & 9.85 & & \\
\hline $\begin{array}{l}\text { Others } \\
\text { Nephtys oligobranchia } \\
\text { Notomastus latericeus }\end{array}$ & $\begin{array}{c}9.10 \\
17.39\end{array}$ & $\begin{array}{l}4.68 \\
4.98\end{array}$ & & & & \\
\hline Total & 293.74 & 81.40 & 89.42 & 82.01 & 37.99 & 86.02 \\
\hline
\end{tabular}


changes in the quality of water and habitat (Rashid and Pandit, 2014). Trophic state index is certainly an important aspect of lake water quality assessment (Yang et al., 2012; Hu et al., 2014). Correlation analysis revealed that the abundance and biomass of macroinvertebrates had significant positive correlations with the trophic state index. In addition, TSI was significantly correlated with DC1 in the DCA analysis, which indicated that eutrophication could be one of the main forces structuring the benthic macroinvertebrate communities.

Macroinvertebrate assemblages were characterized by a lower abundance of Gastropoda and a higher abundance of Oligochaeta and Bivalvia in the algae-dominated regions and transitional regions (Tab. 3). In fact, most lakes have endured a long period of eutrophication in the Jiangsu province since the 1980s (Wang and Dou, 1998). In the algae-dominated regions, the major impact of eutrophication is the occurrence of algal blooms in summer, and the decomposition of algae can significantly decrease or deplete the oxygen content at the water-sediment interface (Cai et al., 2011; Duan et al., 2015). The low oxygen content will strongly influence the survival of some benthic fauna (e.g., reducing the anti-predation behaviors and survivorship of $C$. fluminea) (Saloom and Duncan, 2005). Furthermore, a large population of toxin-producing cyanobacteria can produce a high concentration of Cyanotoxin (mainly Microcystins in the study lakes). B. aerugionsa was observed to accumulate a concentration of Microcystins that was several times higher than the WHO guideline value (Song et al., 2007). Gérard et al. (2009) found that the relative abundance of prosobranchs, pulmonates and bivalves decreased significantly after cyanobacteria blooms. As a result, the frequent cyanobacterial blooms may have a seriously negative effect on some Gastropoda while having little adverse impact on Chironomidae and Tubificidae (Cai et al., 2011). Therefore, the severe environment may favor the Chironomidae and Tubidicidae but inhibit the Gastropoda in the algaedominated regions and transitional regions (Tab. 3).

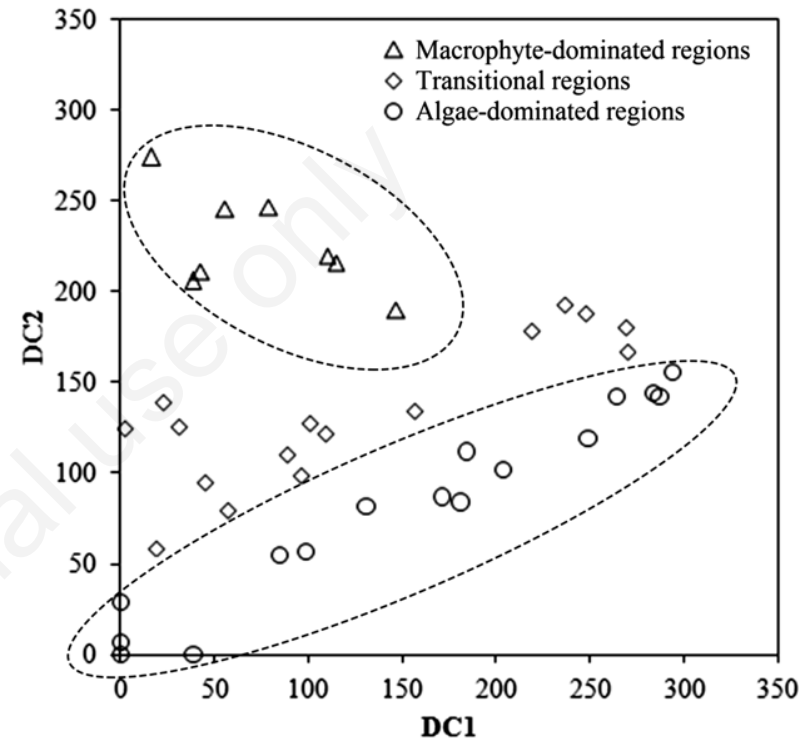

Fig. 6. Scatter plot of the two first detrended correspondence axis obtained by using the environmental parameters.

Tab. 4. Values of correlation coefficients between considered parameters and the first two components of the detrended correspondence analysis (significant correlations at $\mathrm{P}<0.05$ are underlined).

\begin{tabular}{lcc} 
Physical-chemical parameters and Indices & DC1 & DC2 \\
Transparency $(\mathrm{m})$ & -0.222 & 0.168 \\
Depth $(\mathrm{m})$ & 0.239 & 0.101 \\
\hline Conductivity $\left(\mathrm{mS} \mathrm{m}^{-1}\right)$ & 0.185 & 0.102 \\
ORP $(\mathrm{mV})$ & -0.106 & 0.169 \\
\hline $\mathrm{pH}$ & -0.111 & -0.180 \\
Turbidity (NTU) & $\underline{0.385}$ & -0.188 \\
\hline $\mathrm{DO}\left(\mathrm{mg} \mathrm{L}^{-1}\right)$ & -0.145 & 0.173 \\
$\mathrm{TN}\left(\mathrm{mg} \mathrm{L}^{-1}\right)$ & 0.216 & 0.035 \\
\hline $\mathrm{TP}\left(\mathrm{mg} \mathrm{L}^{-1}\right)$ & 0.161 & -0.306 \\
DOC $\left(\mathrm{mg} \mathrm{L}^{-1}\right)$ & 0.056 & 0.031 \\
\hline $\mathrm{COD}\left(\mathrm{mg} \mathrm{L}^{-1}\right)$ & -0.117 & 0.095 \\
Chl- $a\left(\mu \mathrm{g} \mathrm{L}^{-1}\right)$ & -0.159 & $-\underline{0.353}$ \\
\hline Rmp & -0.046 & $\underline{0.335}$ \\
TSI & $\underline{0.402}$ & -0.308 \\
\hline
\end{tabular}

ORP, oxidation-reduction potential; DO, dissolved oxygen; Rmp, ratio of the dry weight of macrophytes to the dry weight of phytoplankton; TSI, tropic state index. 


\section{CONCLUSIONS}

Eight lowland shallow lakes of China were studied to examine the effects of habitat type and trophic state on benthic macroinvertebrate assemblages. Our findings showed that the macroinvertebrate assemblage structure can be highly variable among the three habitats in shallow lakes. Furthermore, there were clear relationships between assemblage structure and trophic state in shallow lakes. Our study is one of the few that has demonstrated the distinct influence of habitat type on macroinvertebrate assemblages in shallow lakes according to the ratio of the dry weight of macrophytes to the dry weight of phytoplankton. These findings will assist lake management by providing a better understanding of the potential impacts of increased nutrient loadings and regime shifts on macroinvertebrate assemblages in shallow lakes.

\section{ACKNOWLEDGMENTS}

This work was financially supported by the Major Science and Technology Program for Water Pollution Control and Treatment (2012ZX07101006), Nanjing Institute of Geography and Limnology, Chinese Academy of Sciences (NIGLAS2012135012) and Natural Science Foundation of Jiangsu Province (BK20131055). We thank many colleagues for their assistance in the field investigation.

\section{REFERENCES}

Al-Shami SA, Rawi CSM, HassanAhmad A, Nor SAM, 2010. Distribution of Chironomidae (Insecta: Diptera) in polluted rivers of the Juru River Basin, Penang, Malaysia. J. Environ. Sci. 22:1718-1727.

Bachmann RW, Horsburgh CA, Hoyer MV, Mataraza LK, Canfield DE, 2002. Relations between trophic state indicators and plant biomass in Florida lakes. Hydrobiologia 470:219-234.

Bazzanti M, Coccia C, Dowgiallo MG, 2010. Microdistribution of macroinvertebrates in a temporary pond of Central Italy: taxonomic and functional analyses. Limnologica 40:291-299.

Cai YJ, Gong ZJ, Qin BQ, 2011. Influences of habitat type and environmental variables on benthic macroinvertebrate communities in a large shallow subtropical lake (Lake Taihu, China). Ann. Limnol. - Int. J. Lim. 47:85-95.

Cai YJ, Jiang JH, Zhang L, Chen YW, Gong ZJ, 2012. Simplification of macrozoobenthic assemblages related to anthropogenic eutrophication and cyanobacterial blooms in two large shallow subtropical lakes in China. Aquat. Ecosyst. Health Manage. 15:81-91.

Carlson RE, 1977. A trophic state index for lakes. Limnol. Oceanogr. 22:361-369.

Chen QW, Yang QR, Li RN, Ma JF, 2013. Spring micro-distribution of macroinvertebrate in relation to hydro-environmental factors in the Lijiang River, China. J. Hydraul. Res. 7:103-112.

Clarke KR, 1993. Non-parametric multivariate analyses of changes in community structure. Austral. Ecol. 18:117-143.

Clews E, Low EW, Belle CC, Todd PA, Eikaas HS, Ng PK, 2014. A pilot macroinvertebrate index of the water quality of Singapore's reservoirs. Ecol. Indic. 38:90-103.
Covich AP, Palmer MA, Crowl TA, 1999. The role of benthic invertebrate species in freshwater ecosystems: zoobenthic species influence energy flows and nutrient cycling. BioScience 49:119-127.

Dinsmore WP, Prepas EE, 1997. Impact of hypolimnetic oxygenation on profundal macroinvertebrates in a eutrophic lake in central Alberta. I. Changes in macroinvertebrate abundance and diversity. Can. J. Fish. Aquat. Sci. 54:2157-2169.

Duan HT, Loiselle SA, Zhu L, Feng L, Zhang YC, Ma RH, 2015. Distribution and incidence of algal blooms in Lake Taihu. Aquat. Sci. 77:9-16.

Gérard C, Poullain V, Lance E, Acou A, Brient L, Carpentier A, 2009. Influence of toxic cyanobacteria on community structure and microcystin accumulation of freshwater molluscs. Environ. Pollut. 157:609-617.

Gabriels W, Lock K, de Pauw N, Goethals PL, 2010. Multimetric Macroinvertebrate Index Flanders (MMIF) for biological assessment of rivers and lakes in Flanders (Belgium). Limnologica 40:199-207.

Hargeby A, Andersson G, Blindow I, Johansson S, 1994. Trophic web structure in a shallow eutrophic lake during a dominance shift from phytoplankton to submerged macrophytes. Hydrobiologia 279:83-90.

Havens KE, Jin K-R, Iricanin N, James RT, 2007. Phosphorus dynamics at multiple time scales in the pelagic zone of a large shallow lake in Florida, USA. Hydrobiologia 581: $25-42$.

Heisler J, Glibert PM, Burkholder JM, Anderson DM, Cochlan W, Dennison WC, Dortch Q, Gobler CJ, Heil CA, Humphries E, Lewitus A, Magnien R, Marshall HG, Sellner K, Stockwell DA, Stoecker DK, Suddleson M, 2008. Eutrophication and harmful algal blooms: a scientific consensus. Harmful algae 8:3-13.

Hu ZX, Guo LY, Liu T, Chuai XM, Chen QK, Shi F, Jiang LJ, Yang LY, 2014. Uniformisation of phytoplankton chlorophyll $a$ and macrophyte biomass to characterise the potential trophic state of shallow lakes. Ecol. Indic. 37:1-9.

Jin X, 1995. Environment of Chinese lakes. Ocean Press, Beijing.

Jin X, Tu Q, 1990. The standard methods for observation and analysis in lake eutrophication. Chinese Environmental Science Press, Beijing.

Jones JI, Young JO, Haynes GM, Moss B, Eaton JW, Hardwick KJ, 1999. Do submerged aquatic plants influence their periphyton to enhance the growth and reproduction of invertebrate mutualists? Oecologia 120:463-474.

Keizer-Vlek HE, Verdonschot PFM, Verdonschot RCM, Goedhart PW, 2012. Quantifying spatial and temporal variability of macroinvertebrate metrics. Ecol. Indic. 23:384-393.

Lindegaard C, 1994. The role of zoobenthos in energy flow in two shallow lakes. Hydrobiologia 275-276:313-322.

Lloyd NJ, Mac Nally R, Lake PS, 2006. Spatial scale of autocorrelation of assemblages of benthic invertebrates in two upland rivers in South-Eastern Australia and its implications for biomonitoring and impact assessment in streams. Environ. Monit. Assess. 115:69-85.

Longhi D, Bartoli M, Nizzoli D, Viaroli P, 2013. Benthic processes in fresh water fluffy sediments undergoing resuspension. J. Limnol. 72:1-12.

Lorenzen C, 1967. Determination of chlorophyll and phaeopig- 
ments: spectorphotometric equations. Limnol. Oceanogr. 12:343-346.

Mackay RJ, 1992. Colonization by lotic macroinvertebrates: a review of processes and patterns. Can. J. Fish. Aquat. Sci. 49:617-628.

Padial AA, Thomaz SM, Agostinho AA, 2009. Effects of structural heterogeneity provided by the floating macrophyte Eichhornia azurea on the predation efficiency and habitat use of the small Neotropical fish Moenkhausia sanctaefilomenae. Hydrobiologia 624:161-170.

Palmer MA, Covich AP, Lake S, Biro P, Brooks JJ, Cole J, Dahm C, Gibert J, Goedkoop W, Martens K, Verhoeven J, Van De Bund WJ, 2000. Linkages between aquatic sediment biota and life above sediments as potential drivers of biodiversity and ecological processes. BioScience 50:1062-1075.

Pan BZ, Wang HJ, Wang HZ, Wang ZY, 2012. Macrozoobenthic assemblages in relation to environments of the Yangtze-isolated lakes. Front. Env. Sci. Eng. 6:246-254.

Phipps GL, Mattson VR, Ankley GT, 1995. Relative sensitivity of three freshwater benthic macroinvertebrates to ten contaminants. Arch. Environ. Contam. Toxicol. 28:281-286.

Principe RE, del Corigliano MC, 2006. Benthic, drifting and marginal macroinvertebrate assemblages in a lowland river: temporal and spatial variations and size structure. Hydrobiologia 553:303-317.

Rashid R, Pandit AK, 2014. Macroinvertebrates (oligochaetes) as indicators of pollution: A review. J. Ecol. Nat. Environ. $6: 140-144$.

Robinson CT, Doering M, 2013. Spatial patterns in macroinvertebrate assemblages in surface-flowing waters of a glaciallyinfluenced floodplain. Aquat. Sci. 75:373-384.

Saloom ME, Duncan RS, 2005. Low dissolved oxygen levels reduce anti-predation behaviours of the freshwater clam Corbicula fluminea. Freshwater Biol. 50:1233-1238.

Scheffer M, 1998. Ecology of Shallow Lakes. Chapman and Hall, London.

Scheffer M, Carpenter S, Foley JA, Folke C, Walker B, 2001. Catastrophic shifts in ecosystems. Nature 413:591-596.

Song MY, Hwang HJ, Kwak IS, Ji CW, Oh YN, Youn BJ, Chon TS, 2007. Self-organizing mapping of benthic macroinver- tebrate communities implemented to community assessment and water quality evaluation. Ecol. Model. 203:18-25.

Statzner B, Higler B, 1986. Stream hydraulics as a major determinant of benthic invertebrate zonation patterns. Freshwater Biol. 16:127-139.

Thomas J, 1990. Mutualistic interactions in freshwater modular systems with molluscan components. Adv. Ecol. Res. 20:125-178.

Traversetti L, Scalici M, Ginepri V, Manfrin A, Ceschin S, 2014. Concordance between macrophytes and macroinvertebrates in a Mediterranean river of central Apennine region. J. Environ. Biol. 35:497-503.

Traversetti L, Ceschin S, Manfrin A, Scalici M, 2015. Co-occurrence between macrophytes and macroinvertebrates: towards a new approach for the running waters quality evaluation? J. Limnol. 74, 133-142.

Underwood GJC, Thomas JD, Baker JH, 1992. An experimental investigation of interactions in snail-macrophyte-epiphyte systems. Oecologia 91:587-595.

Vanni MJ, 2002. Nutrient cycling by animals in freshwater ecosystems. Annu. Rev. Ecol. Syst. 33:341-370.

Vaughn CC, Hakenkamp CC, 2001. The functional role of burrowing bivalves in freshwater ecosystems. Freshwater Biol. 46:1431-1446.

Wang HZ, Xu QQ, Cui YD, Liang YL, 2007. Macrozoobenthic community of Poyang Lake, the largest freshwater lake of China, in the Yangtze floodplain. Limnology 8:65-71.

Wang SM, Dou HS, 1998. Chinese lake catalogue. Science Press, Beijing.

Weatherhead MA, James MR, 2001. Distribution of macroinvertebrates in relation to physical and biological variables in the littoral zone of nine New Zealand lakes. Hydrobiologia 462:115-129.

Yang J, Yu XQ, Liu LM, Zhang WJ, Guo PY, 2012. Algae community and trophic state of subtropical reservoirs in southeast Fujian, China. Environ. Sci. Pollut. Res. 19:1432-1442.

Żbikowski J, Kobak J, 2007. Factors influencing taxonomic composition and abundance of macrozoobenthos in extralittoral zone of shallow eutrophic lakes. Hydrobiologia 584: $145-155$. 